\title{
The nature of financial literacy
}

\author{
Richard M.S. Wilson*, Anne Abraham, **
} and Carolynne Mason*

*LOUGHBOROUGH UNIVERSITY, U.K., **UNIVERSITY OF WESTERN SYDNEY, AUSTRALIA

\section{CONTENTS}

Abstract

Keywords

3.1 Introduction

000

3.2 What is literacy?

000

3.2.1 Some key ideas

3.2.2 Meaning-making

3.2.3 The problem of illiteracy

3.2.4 Literacy in different fields

3.3 Financial awarenes

3.3.1 Exploring the notion of financial awareness

3.3.2 Financial literacy and financial awareness

3.4 Defining financial literacy

3.4.1 Extending the notion of financial awareness

3.4.2 Financial literacy studies

3.4.3 Why is financial literacy important?

3.4.4 Attempts to address financial literacy

3.5 Implications and conclusion 


\begin{abstract}
The notion of financial literacy is not a new one. It is widely perceived as being important, hence something to be encouraged in those who are not financially literate, as exemplified by the existence of organisations dedicated to generating financial literacy in, for example, Australia, Canada, the U.K., and the U.S.A.

But what does the term financial literacy actually mean? What distinguishes a financially literate individual from one who is financially illiterate? This chapter investigates aspects of financial literacy in particular contexts (embracing households and formal organisations - whether profitseeking enterprises or public sector bodies). As a prelude to defining what is meant by financial literacy, however, the basic idea of literacy itself (subsuming numeracy) is considered.

The fraught confusion over financial awareness and financial literacy, often viewed as being synonymous expressions, is addressed. This confusion arises (at least in part) from inadequate definitions of financial literacy (which clearly has implications for its operationalisation). These limitations are explored and a fuller definition of financial literacy is provided as a point of reference for accounting educators.
\end{abstract}

\title{
Keywords
}

financial awareness, financial literacy, literacy, meaning-making, numeracy

\subsection{Introduction}

The main aims of this chapter are:

- to discuss what is meant by literacy (subsuming numeracy);

- to consider the importance of literacy and the problem of illiteracy;

- to highlight the role of meaning-making in the context of being literate;

- to critically compare financial awareness and financial literacy; and

- to define financial literacy and assess its importance as a cornerstone of accounting education.

In Section 3.2 we begin by looking at the essence of being literate (and numerate), consider meaning-making (or sense-making) as being at the heart of what it means to be literate, and review the use of the term 'literacy' in a number of different contexts.

The discussion in Section 3.3 moves on to concerns which exist over an individual's ability to use financial information effectively, and some of the implications of this. Studies looking at particular aspects of financial awareness are examined, and questions are raised about the adequacy of this construct for both accounting educators and accounting practitioners. An argument is presented which suggests that financial awareness and financial literacy are not synonymous expressions.

Financial literacy is defined in Section 3.4 as being a complex phenomenon which needs to be defined in relation to meaning-making, on the one hand, and purposive behaviour, on the other.

Section 3.5 concludes the chapter by looking at the need for accounting educators to focus on financial literacy in the design, delivery, and assessment of their programmes.

Many of the examples given and literature cited reflect the authors' familiarity with the jurisdictions in which they are located. Nevertheless, their belief is that the issues raised are not restricted to Australia and the U.K., but have broader applicability.

Let us start by examining the notion of literacy. 


\section{R. M. S. Wilson, A. Abraham and C. L. J. Mason}

\subsection{What is literacy?}

\subsubsection{Some key ideas}

In her book Literacy, Margaret Jackson attempts to respond to the question: What is literacy? She notes that the term literacy is 'very rarely carefully defined' (1993, p. 1). That said, literacy is defined in the Collins Dictionary as 'the ability to read and write' or 'the ability to use language effectively'. The Oxford English Dictionary states that literacy is 'The quality or state of being literate; knowledge of letters; condition in respect to education, ability to read and write.' These definitions probably encapsulate most people's initial thoughts about literacy. However, the discussion that follows shows that these definitions fail to grasp much of the complexity of what it means to be literate.

It is argued here that a literate individual is one who possesses a set of skills and abilities (including reading, writing, speaking, being numerate, and the ability to reflect) which allows him/her to locate and make use of resources in order to achieve objectives. The resources available to us in a complex society are extensive, with books being almost the tip of the iceberg. (See Stevenson et al., Chapter 19 - this volume.) The objectives for those who are literate are also probably infinite. Jackson outlines a typical day where she begins by reading the shampoo bottle in the shower and moves through the day until she finishes by reading in bed. She states that, during the day, she has used print to 'inform, to remind, to persuade, to keep in touch, to amuse, to instruct and to disturb' (1993, p. 90). It is literacy that allows her to successfully achieve these outcomes, and it is these skills that allow individuals to develop as individuals and contribute to the development of the society of which they are a part. The functional nature of literacy is therefore apparent. Functional literacy can be defined as:

A person is literate when he has acquired the essential knowledge and skills which enable him to engage in all those activities in which literacy is required for effective functioning in his group or community.

(UNESCO definition, 1962, cited in Oxenham, 1980, p. 87)

Burnet (1965) discussed the idea of functional literacy, emphasising that there is a difference between acquiring the skills to be able to read and write, on the one hand, and becoming literate, on the other. Functional literacy is viewed by Burnet as being:

the key that unlocks the door to the future, because the person who has achieved it has learned to learn for himself, and has thus gone a long way toward making his fundamental right to education a reality. He no longer has to be content with what other people choose to teach him; he can find out for himself what he wants to know. He can improve his occupational status and enrich his leisure. He has learned to reflect on what he reads, to make comparisons and draw his own conclusions.

(1965, p. 14)

Literacy, then, is not simply about reading, writing, and being numerate (though there is nothing simplistic about the acquisition of these skills). In these few sentences Burnet indicates that literacy is shown, at the very least, to be about:

- learning;

- achieving status;

- achieving human rights;

- knowing; 
- making choices;

- improving occupational status and wealth;

- improving leisure pursuits;

- making comparisons;

- creating and confirming conclusions.

There appears to be little that we value in Western society that is not affected by literacy. But in what way does literacy allow all these individualistic and societal outcomes to happen? This takes us on to the crucial role of meaning-making.

\subsubsection{Meaning-making}

As an introduction to meaning-making (or sense-making), reference can be made to:

- the literature of sociology and social psychology (such as Berger \& Luckmann, 1966, Weick, 1979, 1995, Weick et al., 2005);

- that of organisational theory (such as Maitlis, 2005, Maitlis \& Lawrence, 2007);

- that of accounting (such as Boland, 1980, 1984, 1987); and

- the social construction and socio-linguistics of literacy (see Cook-Gumperz, 1986, Gee, 1990).

An interesting (albeit brief) comment on making sense of the current Global Financial Crisis (GFC) relative to the crash of 1929 through the use of narrative (i.e. story telling - an important form of meaning-making) is given by Wagner (2011); and an insightful study of meaning-making using three different professional groups in Singapore (auditors, engineers, and architects) is reported by Cheuk (2002).

Jackson (1993) emphasises the contextual nature of literacy and highlights the view that the more complex the society, the more complex the notion of literacy becomes. In the Preface to her book, Jackson states: 'Literacy offers us access to information, ideas, opinions and by creating the potential for reflecting, provides opportunities for making and communicating meaning, and for learning.' Literate individuals are able to make meaning as a basis for learning and this, we would argue, along with Jackson, is the key element of literacy. In order to operate effectively within the context of a complex society (or in one of its components, including households and more formal organisations), individuals need to be able to make sense of and understand the world in which they operate. In less complex societies, hunters need to respond to their environment in order to survive. In more complex societies, a great deal of the information required in order to make sense of the environment is contained within the symbolic representation systems of words and numbers. Individuals' chances of operating effectively are greatly enhanced by their being able to make sense of these word and number systems, and they do this by being both literate and numerate.

While recognising that literacy involves individuals being able to read and write, Jackson's definition above also emphasises that, on their own, these skills are not sufficient for an individual to become literate: individuals must also be able to reflect in order to make, and communicate, meaning and to learn.

The key questions here are:

- How do users of information (whether of a financial nature or not) extract meaning and make sense of it?

- What courses of action might this stimulate? 


\section{R. M. S. Wilson, A. Abraham and C. L. J. Mason}

Each user is a distinct meaning-making individual, and each will make use of available information (words, numbers and other symbols) to construct a picture of the situation which he or she faces. Such constructions will vary from one person to another and, since they are made in a setting which includes interactions with other people, they are social constructions reflecting the unique perceptions of the social or organisational reality facing each person who is involved. For example, in difficult market conditions, a sales representative may have missed last month's sales quota by $£, 50,000$. Her view of this shortfall is likely to differ from that of her demanding boss, on the one hand, and those of her envious peers, on the other, yet the number in question (i.e. $£^{50,000)}$ is common to all parties. That which differs from one person to another, and from one situation to another, is how sense is being made of - or meaning being attributed to - the variance of $£, 50,000$ and what might be done about it.

Literate individuals have certain opportunities but, in order to utilise these effectively, they must be active and draw on a variety of personal skills (including their ability to read, write, speak, handle numbers, and reflect). This pro-active theme is expanded by the use of verbs such as reflecting, meaning-making, communicating, and learning. As we saw earlier, Burnet (1965) used similar verbs in her description of functional literacy. However, in his pioneering (1957) study, Hoggart showed that literacy is not always used to its best advantage and that, depending on the context, the changes which it brings are not necessarily positive ones.

The points raised so far can be represented diagrammatically as shown in Figure 3.1. Figure 3.1 shows literacy to be a process whereby individuals use a combination of their skills plus available resources to make sense of - or understand - those resources in order to achieve objectives. The sub-section that follows examines illiteracy in order to further consider what being literate entails, and to examine why being literate and numerate is considered to be important.

\subsubsection{The problem of illiteracy}

If being literate and numerate allows individuals to achieve desired objectives, then being illiterate and innumerate is problematic because it prohibits individuals from achieving desired objectives, and this necessarily presents problems at both individual and societal levels. Concerns over the prevailing standards of literacy and numeracy are rarely out of the newspaper headlines. Within the U.K., for example, there is a widely held concern that standards of literacy and numeracy

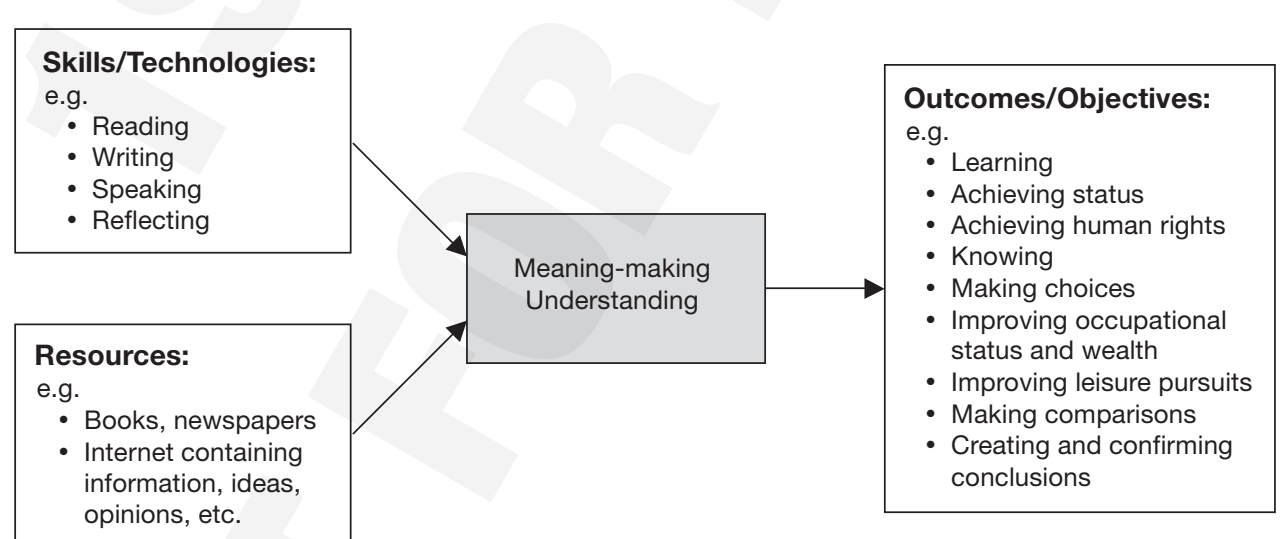

Figure 3.1 Literacy viewed as a meaning-making process 
have been falling dramatically, with negative consequences for both the individuals concerned and for society at large (see below). Improving literacy and numeracy have been high priorities for successive U.K. governments.

It is not only in the U.K. that literacy is on the agenda. For example, in the U.S.A., President Clinton stated (on International Literacy Day, in September 1994):

Literacy is not a luxury, it is a right and a responsibility. If our world is to meet the challenges of the twenty-first century we must harness the energy and creativity of all our citizens.

Illiteracy is conventionally portrayed as having negative consequences. As Sir Claus Moser noted (The Sunday Times, 1993, p. 9): 'The illiterate person is tragically handicapped. Without well-developed literacy skills an individual is an outsider [in his/her own] culture.' In other words, 'Literacy is good, illiteracy is bad.' This is clearly a value judgement and, while it appeals intuitively, understanding why illiteracy is problematic contributes towards our understanding of the importance of literacy in general (and therefore of financial literacy in particular).

Before considering examples of illiteracy, it is important to highlight that, as noted above with regard to literacy (see Jackson, 1993), the problems associated with illiteracy are contextspecific. Burnet (1965, p. 11) stated:

There has always been illiteracy, but it has not always been a problem - not everywhere, at least. In isolated, self-sufficient societies, where life followed a traditional pattern and nobody knew how to read and write, illiteracy was no problem. But there are few such societies left . . As technical development moves faster and faster, and as populations increase, the problem of illiteracy becomes more and more acute.

Only as societies become more complex and technologically advanced does illiteracy become a problem. Individuals need to be well equipped in order to respond to advances within the social and economic context. Literacy is important because it enables individuals to function more effectively in ever-changing contexts which become ever more complex. Burnet (1965, p. 8) cites the example of one textile mill owner in Guatemala who stated that 'we will not hire an illiterate man'. The mill owners had established their own school to teach workers to read and write, not as a result of philanthropy, but because: 'Experience showed that literate workers absorbed training faster and worked more efficiently. Productivity increased, and this permitted higher wage rates along with greater profits.'

According to this viewpoint, the benefits of literacy can be measured in human and economic terms, at both individual and societal levels. Literacy contributes to the well-being of the individual and also to the well-being of the society of which that individual is a part. Illiteracy is viewed as being negative because it prevents the rewards of advances being reaped by either individuals or society. Illiterate individuals cannot function as effectively as literate ones can in the context of complex societies.

Illiteracy, then, is potentially problematic both for individuals and for society. The cost of illiteracy within the U.K. as elsewhere is not only measured in lost earnings, but also in additional public expenditure on education, health, welfare, and the criminal justice system. (See The Times, 11 December 2006, p. 2, and The Times, 20 March 2008.) According to the European Commission, in terms of competitive performance, the U.K. is held back by having too many illiterate and innumerate adults with no qualifications. A report from the World Literacy Foundation (Cree et al., 2012) noted that 20 per cent of adults in the U.K. are 'functionally illiterate', and it was reported by the Centre for Policy Studies (Gross, 2010) that there was an epidemic of 


\section{R. M. S. Wilson, A. Abraham and C. L. J. Mason}

illiteracy in London, with one million people being unable to read (cited in Atewill, 2010). Given the continuing decline in low-skilled jobs, this is a serious problem. Almost 20 per cent of children in the U.K. leave school without the reading skills required to be a productive member of society, with the equivalent figure for Shanghai being only 4 per cent (see Moynihan, 2012). And the U.K. is a member of the G8 and G20 groups of advanced nations.

Turning to numeracy, research undertaken by KPMG (see Frean, 2008) shows that there is a widespread problem with basic mathematical skills among the U.K.'s adult population (whether this involves simple mental arithmetic while shopping or helping children with their homework) (See also Woolcock, 2012.) The mathematical attainment of children in the U.K. lags well behind that of their counterparts in Hong Kong, Japan, Singapore and Taiwan at all ages. (See Buchanan, 2013; Bennett, 2008; Hurst, 2013). This matters because it has the potential to impact negatively on the U.K.'s leadership in financial services. Furthermore, it is commonplace to find journalists setting a bad example by making numerical errors in their writing, such as failing to distinguish between a percentage change and a change in percentage (see Brooks, 2007).

There is a problem in both the U.K. and the U.S.A with too many young people leaving school with inadequate numeracy skills. One estimate (Sugden, 2011) put the figure at 25 per cent of U.K. school leavers being 'functionally innumerate' (i.e. unable to use simple mathematics to solve everyday problems), whilst the figure mooted for school leavers in the U.S.A has been estimated at 32 per cent (Walters, 2012).

Tracey Bleakley, Chief Executive of the Personal Finance Education Group (PFEG), noted:

There is no question that maths skills need to improve. At present too many young people are leaving school without the basic maths they need to make a whole range of financial decisions, from setting a budget to planning borrowing and saving.

(Cited in Budworth, 2012)

This reinforces the view that: 'pupils need to become more comfortable with using numbers, including percentages and fractions used in the world of finance' (Sugden, 2011, p. 8). (See also Sugden, 2009, p. 17.) This problem applies beyond pupils at school to include university students who have to be given remedial classes in mathematics (e.g. see Frean, 2007). There is a good deal of evidence to show that schools in both the U.K. and the U.S.A. fail to prepare their pupils adequately with literacy and numeracy skills for higher education: see, for example, Blair et al. (2004); Birkhead (2006); Times Higher Education (2007); Frean et al. (2007); Anon (2008); Hanushek \& Peterson (2011); Peterson et al. (2011).

There have been many reports in the U.K. of employers being either unable to fill vacancies due to applicants' poor literacy and numeracy skills (e.g. see Grimston, 2010b), or having to provide remedial training in mathematics and English to new recruits (e.g. see The Times, 14 October 2009, p. 9; Street-Porter, 2009; King, 2010). These limitations are inevitably holding back the U.K.'s economic recovery from the Global Financial Crisis which began in 2008 .

Having established that the importance of literacy and numeracy is reflected in the individualistic and societal benefits that arise from being literate and numerate, a discussion of the usage of the term literacy within other fields follows.

\subsubsection{Literacy in different fields}

While this chapter is primarily concerned with financial literacy, it is important to note that the term literacy is one that has been adopted by scholars and practitioners from a variety of 
backgrounds to indicate a level of proficiency within a given field. Some examples of using the term literacy in different fields are included here, along with a brief discussion of the implications for financial literacy.

A search of the literature identifies a host of studies that include literacy in their title. These include:

- academic literacy (Saunders, 2010; and a job advertisement in Times Higher Education, 10 January 2013, p. 56);

- $\quad$ biblical literacy (Beal, 2009);

- computer literacy (Day, 1987);

- $\quad$ economic literacy (Whitehead \& Halil, 1989);

- electronic literacy (Craver, 1997);

- $\quad$ graphicacy (Milner \& Hill, 2008);

- $\quad$ health literacy (Cafferkey \& Doyle, 2011; Sorensen et al., 2012; Barrow, 2012);

- $\quad$ information literacy (Kulthau, 1991; Mutch, 1997; Jackson \& Durkee, 2008; Hepworth \& Walton, 2009);

- internet literacy (Martin, 1997);

- mental health literacy (Furnham, 2011);

- multi-media literacy (Hofsteter, 1995);

- $\quad$ political literacy (Institute of Education, 1983);

- $\quad$ risk literacy (Henderson, 2009a);

- $\quad$ scientific and technological literacy (Layton, 1994);

- $\quad$ statistical literacy (Haack, 1979);

- $\quad$ sustainability literacy (Stibbe, 2009);

- teleliteracy (Bianculli, 1992); and

- $\quad$ visual literacy (Wilde, 1991).

An examination of this literature shows that some of the characteristics of literacy highlighted earlier in this section are also to be found in these other uses of the term. However, the term literacy is often used with little or no care being paid to its definition. Definitions are sometimes not offered at all, and those that are offered are frequently found to be deficient.

It is also clear that much of the literature that examines literacies in other fields is written as a result of concerns over standards. These concerns could be expressed by educational practitioners who worry that their students are not performing well, or by managers anxious that, for example, the expected benefits of some new computer software have failed to materialise. Frequently, concerns over standards can be linked to concerns over a lack of understanding (or meaning-making) on the part of the individuals involved rather than being due to a lack of basic skills. In his book on statistical literacy, for example, Haack (1979, p. x) stated that the aim of the book was to get away from formulae when teaching statistics. Instead he stated: 'the purpose is to get students to understand the principles of hypothesis testing without trying to make them decide which of many tests is "best". Without actually offering a definition of statistical literacy (other than by offering it as a mechanism to overcome statistical doublespeak), Haack deliberately moved away from the actual techniques used in statistical analysis and has, instead, viewed literacy as being about understanding. On p. 3, he states: 'Our emphasis is on understanding and interpreting the statistics.'

More recent work on statistical literacy has been undertaken in the U.K. by MacInnes. (See MacInnes, 2013, http://www.sps.ed.ac.uk/ and http://www.rss.org.uk/.) There is much to learn from examining information literacy, not least because this is one of the most frequently identified 


\section{R. M. S. Wilson, A. Abraham and C. L. J. Mason}

adoptions of the term literacy. There is a large amount of multi-disciplinary interest in the concept of information literacy. It is almost trite to observe that there has been a huge increase in the sheer volume of information in the last 50 years due to developments which include improvements in mass production printing techniques, the wide availability of personal computers and, more recently, the arrival of the internet. Schuman (1991, p. 4) stated:

A weekly edition of the New York Times contains more information than the average person was likely to come across in a lifetime in seventeenth-century England. The English language now contains 500,000 words, five times more than in Shakespeare's lifetime. The collection of the large research libraries has doubled in the last fourteen years. We readily throw out with our nightly garbage more print than past generations dreamed it was possible to own.

The availability of all this information has led to concerns over how to manage it, and from this has stemmed much of the interest in information literacy. Individuals from two disciplines in particular, library studies and computing, have made information literacy a focus of their concerns. This inter-disciplinary interest has ensured that there is no single definition of, or approach to, information literacy.

The American Library Association's Presidential Committee on Information Literacy (1989, p. 1) defined information literacy in the following way:

To be information literate, a person must be able to recognise when information is needed and have the ability to locate, evaluate, and use effectively the needed information. Ultimately, information literate people are those who have learned how to learn. They know how to learn because they know how knowledge is organised, how to find information, and how to use information in such a way that others can learn from them. They are people prepared for lifelong learning, because they always find the information needed for any task or decision at hand.

There are clearly parallels that can be drawn between this definition of information literacy and the earlier definition of literacy offered in this chapter (see Figure 3.1). The 1989 definition implies that information literacy is important because it enables individuals, inter alia:

- to learn how to learn;

- to be prepared for lifelong learning; and

- to find the information needed for any task or decision at hand.

A key theme in this definition is learning. The objective for information literate individuals is to learn. Learning was identified earlier as being one of the outcomes of being literate. Once again there is an emphasis on individuals needing certain skills and resources in order to achieve desired outcomes.

Further, it has been suggested that it is appropriate that information literacy not be 'taught as a separate course but [be] integrated with learning across the curriculum . . . and . . . developed around the basic need of every person to find meaning and understand his or her world' (Kuhlthau, 1991, p. 9). This view of information literacy prioritises the process of meaning-making and the implication is that this relies on more than the development of a set of key skills within a classroom environment. The advent of computers was expected to be associat1ed with improvements in the ways in which businesses and other organisations functioned as a result of the increased capacity for processing data which, it was anticipated, would lead to improved efficiency and better decision-making. 
Mutch (1997, p. 377) suggested that these aspirations may not have been realised because 'computers are able to generate huge quantities of data which are either misused by or overwhelm those who are on the receiving end'. Among the reasons which he suggests for this ineffective use of computers are that information itself is not well understood, and the relationship between data and knowledge is often not recognised. Concerns are directed at the process of acquiring, maintaining, and delivering data rather than understanding exactly why data is required, what use it will be, and in what way it will be used. This applies equally to financial data.

Mutch argues that information is better treated as a process rather than as a thing. While he recognises that there is considerable support for information being regarded as a thing, including the attempts by many to capitalise information as a business asset, Eaton \& Bawden (1991) claim that information is different from other assets in that it is not consumed in use, and is dynamic and unpredictable. (See also Oppenheim et al., 2003a, 2003b, 2004; Wilson \& Stenson 2008.) These qualities stem from the fact the information has meaning endowed by the user. Similarly, Boland (1987, p. 377) stated that:

[Information] is not a resource to be stockpiled as one more factor of production. It is meaning, and can only be achieved through dialogue in a human community. Information is not a commodity. It is a skilled human accomplishment.

Again, the key element that is of interest here is understanding or meaning. Information is only of use if it is understood and used appropriately. In other words, the availability of resources, generically termed information, and the combination of hardware and skills to access these resources, are not sufficient to ensure positive outcomes, including good decision-making. A crucial part of the process has been omitted, namely meaning-making or understanding.

Thus it appears that the term literacy appears to be borrowed when a problem is in need of a solution and this is often when individuals are ineffective in being able to make meaning or sense-make in the context of increasingly challenging and complex environments. With statistical literacy, it was students' inability to understand the statistics they use, while for information literacy, the problems stem from the large volume of data and people's inability to use information effectively.

In summary, this section has indicated that being literate enables individuals in complex societies to achieve a range of objectives through engaging in meaning-making. In stark contrast, illiteracy was seen to be problematic in that it prevents both individuals and the societies in which they operate from achieving their full potential. Literacy was seen to be a term and a concept that have been adopted in a number of different fields, too often without adequate definitions being offered. It was noted that the adoption of the term literacy was often linked to concerns about a lack of competence or a lack of understanding. Problems present themselves, such as an inability to use a computer or an inability to make good financial decisions, and improving levels of literacy is commonly seen as being the answer. This can also be argued for financial literacy since this is also a term that has arisen as a result of the identification of a problem (e.g. when individuals have been shown to be ineffective in their use of financial information). The implications of a perceived lack of financial literacy can be far-reaching as the following two examples indicate.

In a macro-economic context, the credibility of the U.K.'s Office for National Statistics (ONS, a branch of government) was under question when numerical errors caused it to announce that economic growth in the building sector was 2.3 per cent in the second quarter of 2011 . Seven hours later a corrected figure of 0.5 per cent was announced. This is not the ONS's first mistake, and such errors are serious because they affect the financial markets. (See Hopkins \& Clark, 2011.) 


\section{R. M. S. Wilson, A. Abraham and C. L. J. Mason}

Another example of this propensity for making errors occurred in 2012 when civil servants advising the U.K.'s then Secretary of State for Transport advised her to award the franchise for operating trains on the lucrative West Coast Main Line route from London to Scotland to First Group rather than to Sir Richard Branson's Virgin Trains. After the controversial decision was announced, Sir Richard sought a judicial review from which it emerged that the advisors had failed to allow for the impact of inflation in the figures on which they had provided their advice, thereby causing considerable political embarrassment to the government - and annoyance to Virgin Trains which had previously held the franchise, and which is continuing to operate West Coast Main Line services on an interim basis while the lengthy - and expensive - bidding process is repeated. (See Pank, 2012; and The Times, 16 January 2013, p. 2.)

While this preliminary discussion has examined the nature of literacy, and its adoption in other guises, the section that follows examines another concept relevant to understanding the nature of financial literacy - that of financial awareness.

\subsection{Financial awareness}

\subsubsection{Exploring the notion of financial awareness}

While research dedicated to financial literacy has grown substantially in recent years, the earliest body of research in this field concerned financial awareness. This section concentrates mainly on a number of influential academic studies undertaken by researchers at Cardiff University in the U.K. where financial awareness was examined in a number of different contexts. But first, as a point of reference, it is informative to consider one of the few published non-academic empirical studies of managers' financial awareness. This was undertaken in 1992 by a market research agency (Taylor Nelson Financial) on behalf of a professional firm (KPMG Management Consulting), and we can set its findings against some more recent practitioner studies from the Association of Chartered Certified Accountants (ACCA) published in 2012, before returning to review the Cardiff studies.

The KPMG study was commissioned more as a practice development (i.e. marketing) exercise than as a rigorous inquiry seeking to generate real insights into the causes and consequences of managers' financial awareness, and it did achieve a good deal of media attention when the results were published. By means of a financial quiz (see Taylor Nelson Financial, 1992), it was found that non-financial managers in the U.K.'s top 1,000 companies (covering manufacturing, distribution, and service sectors) showed a lack of even the most basic levels of financial awareness. For example, there was little awareness of the effects of a lack of cash, the problems of rapid growth, the role of working capital, or the dangers of high gearing on a company's well-being, and little knowledge about how to undertake investment appraisal. This reflects an alarming state of affairs.

In a study of 500 investors, customers, suppliers and other stakeholders drawn from Canada, the U.K., and the U.S.A., the ACCA (2012a) found that 50 per cent of respondents rather surprisingly named the annual report as being their primary (or, in some cases, their only) source of information about a company, and that the majority of those respondents now read this more carefully than they did prior to the GFC. (See Adler, Chapter 23 - this volume.) In a second report, the ACCA (2012b) predicted that the accounting profession will continue to lose credibility if it fails to educate the public and its stakeholders about its value - but this view that there is a widespread lack of public understanding of the role that accountants play in driving the success of organisations in all sectors is compounded by the dramatic changes that impact 
on the context in which accountants must operate (stemming from, for example, increases in global competition, complexity, the rate of technological change, regulation, and decreases in product life cycles: see Flood, Chapter 4 - this volume). A third ACCA report (see Fast Futures Research, 2012) highlighted these changes, and noted that the importance of being financially aware is not reduced by their dynamic impact.

There is, as shown by these reports, a real problem over financial awareness. The work of the Cardiff researchers also raised questions about the ways in which financial information is understood by individuals, and this has implications for developing insights into financial awareness as a prelude to defining financial literacy.

Bartlett \& Chandler (1997) replicated the earlier work of Lee \& Tweedie (1975a, 1975b, 1976, 1977) in order to examine whether changes within the financial reporting environment (e.g. the introduction of a cash flow statement, a statement of recognised gains and losses, and an operating and financial review) had affected the ways in which financial reports were read by shareholders. They concluded that the annual report was not widely read despite 84 per cent of respondents stating that they made their own investment decisions. Bartlett \& Chandler also found that the narrative sections of the annual report attracted the wider readership. This leads one to ask whether small shareholders were more confident in dealing with words rather than with numbers and, if so, whether this might be due to a lack of financial awareness.

Peel \& Pendlebury (1998) focussed on financial awareness in their follow-up to a previous study (Peel et al., 1991) focussing on employee share ownership. They accepted that the term 'financial awareness' had many different meanings and could therefore be measured in a number of different ways, yet they did not offer a definition on which their measure was based.

One of the most interesting issues raised by Peel \& Pendlebury was their suggestion that individuals with greater financial awareness were more likely to become members of a share ownership scheme than those who become members of such a share scheme, achieving greater financial awareness as a consequence (1998, p. 45).

In addition, the employees in Peel \& Pendlebury's study, like the shareholders in Bartlett \& Chandler's work, preferred company news bulletins and magazines to annual reports, indicating a preference for narrative presentation rather than numeric. The narrative report may have allowed individuals lacking in financial expertise to feel confident that they understood the information presented when, in fact, they did not, because they may have merely recognised the words rather than understanding the concepts underpinning those words.

Both of these Cardiff studies found results which implied that annual reports were not well read or understood despite a considerable amount of effort aimed at achieving these outcomes. The findings highlighted the need to understand in far greater detail exactly how individuals gained the skills needed to be able to analyse and understand financial information and, having gained these skills, how they might be used. The results have contributed towards understanding more about financial awareness, but they also signal that financial awareness is a complex issue. (See Lucas \& Mladenovic, Chapter 6 - this volume.) Another problem with both of these studies is that there was no discussion of either the causes or the consequences of a lack of financial awareness. Why were these individuals unable/unwilling to make full use of annual reports? What were the implications of not using the information with which they had been presented?

Two other Cardiff-based researchers, Marriott \& Mellett, carried out a series of studies examining the financial awareness of managers in the U.K.'s National Health Service (NHS). The introduction of an internal market to the NHS meant that decisions with financial consequences within the NHS were often made by those with a clinical training rather than those with a financial background. Marriott \& Mellett $(1991,1994,1995,1996)$ set out to assess the 


\section{R. M. S. Wilson, A. Abraham and C. L. J. Mason}

adequacy of managers in the NHS to make these decisions. They were concerned that, if the necessary financial skills were lacking, incorrect decisions that might have financial consequences could be made.

From their pilot study Marriott \& Mellett (1991, p. 23) concluded that:

There exists a gap between managers' financial skills and those which will be needed to operate efficiently the novel procedures in the reformed NHS . . . The full extent of the need for financial training within the NHS has not been identified. . Unless these steps are taken, the NHS will not operate to its potential as those taking decisions will not be in a position to make full or appropriate use of the information available.

One of the main contributions of the Cardiff NHS studies is that they highlighted a lack of financial awareness on the part of managers within the NHS. Individuals were expected to make decisions requiring an understanding of their financial consequences without necessarily having the financial skills that enabled them to make those decisions in an effective manner. These findings were important both for the NHS and for other public sector organisations which have undergone similar reforms, whereby individuals may be expected to make decisions requiring an understanding of their financial consequences which they are ill-equipped to make.

In their attempt to assess the ability of NHS managers to make sound decisions requiring an understanding of their financial consequences, Marriott \& Mellett used a 'financial skills index' as a proxy for financial awareness. However, while it is possible to state that the individuals in this study did have limited financial skill as measured by the instrument developed by Marriott $\&$ Mellett, this does not guarantee that the latter's conceptualisation of 'financial skill' is valid, or that the way in which it has been measured is necessarily sufficient. Indeed, there is no single external measure of financial awareness (Marriott \& Mellett, 1996, p. 72).

Despite inadequate conceptualisation, financial awareness was measured using survey instruments by both Peel \& Pendlebury (1998) and Marriott \& Mellett (1996) with the latter study defining financial awareness as 'the manager's ability to understand and analyse financial information and act accordingly' (1996, p. 64).

These authors measured the respondents' ability to define and calculate a restricted number of accounting measures, but being able to define and calculate is not necessarily synonymous with being able to understand and analyse. In this case, respondents may still have been financially aware using Marriott \& Mellett's (1996) definition without being financially literate. Unlike the other studies at Cardiff, Marriott \& Mellett were concerned with suggesting possible consequences of this lack of financial awareness. However, these consequences were merely hypothesised: there was no empirical evidence of the consequences offered by Marriott \& Mellett.

Numerous other questions remain unanswered despite this research. For example:

- Did the users understand the budgets they received?

- Did the individuals who prepared the budgets feel that their recipients were using them effectively?

- Did the individuals in the sample really feel that the quality of their decisions was being affected by their lack of financial skills?

- Was there any evidence to suggest that 'bad' decisions were actually being made?

The researchers at Cardiff divorced their studies from the actions of the individuals (i.e. the intended readers of financial information). The reason that researchers were concerned with an individual's ability to understand and analyse financial information is that his/her actions were thought to depend on this ability. So, for example, a shareholder's ability to understand annual 
reports is thought to affect his/her investment decision-making. We now know that shareholders do not read annual reports thoroughly and yet we do not know what impact, if any, this has on their investment decision-making behaviour.

The Cardiff studies were premised on the underlying assumption that a lack of understanding of financial matters has negative consequences, but they did not actually demonstrate a link between financial awareness and an individual's ability to make sound decisions. Rather, the effect of financial information on decision-making behaviour has been ignored both as a theoretical possibility and as an empirical reality.

There also appears to be a widely held belief that more information (or clearer information) will lead to greater levels of financial awareness. Lee \& Tweedie's work in the 1970s highlighted problems over shareholders not reading annual reports. In the years that followed, great emphasis was placed on 'improving' the annual reports and this was expected to result in improved usage of the reports by shareholders. A similar response has been offered to the identification of poor levels of consumers' financial understanding. An alternative approach is to focus on improving individuals' financial skills. What seems to be missing, however, is an attempt to understand why there is so much misunderstanding. Why are there poor levels of understanding? Why do shareholders not read the reports? How do these individuals compare with those who do understand reports? What does it mean to understand the reports? Thus, this early work at Cardiff showed that individuals did not make good use of financial information and that this may have been due, at least in part, to a lack of financial awareness.

\subsubsection{Financial literacy and financial awareness}

So what is the relationship between financial literacy and financial awareness? We suggest that financial literacy must be conceptualised as a complex phenomenon whereby individuals make sense of information in order to assess the financial consequences of their decisions made in order to achieve desired outcomes. To this end, financial awareness is a part of financial literacy because, in order to be financially literate, individuals must be financially aware. However, being financially aware is a necessary but not a sufficient condition for being financially literate: individuals may be financially aware without being financially literate. For example, the NHS managers in Marriott \& Mellett's studies may have performed exceptionally well when assessed by the 'financial skills index' and yet still have failed to make effective decisions requiring an understanding of their financial consequences because they had not understood the factors relevant to their decision-making and can therefore be deemed to be financially illiterate. Alternatively, they may have performed badly on the test and still have been financially literate, as demonstrated by their being able to locate and understand the financial information relevant to their decisionmaking, and to predict the financial consequences of decisions made.

Financial awareness has been examined as a measure of people's understanding of terms that already exist (i.e. terms such as balance sheet, budget, and depreciation). However, the relationship between people's understanding of these terms and their ability to make effective decisions has not been empirically examined. Individuals may have a very good knowledge of certain financial terms, and therefore be financially aware, while still being unable to recognise the relevance of other information which prevents them from recognising the financial consequences of any decision which they may make. This may ultimately prevent them from achieving their desired outcomes so, in this instance, an individual would be financially aware but financially illiterate.

We now turn to developing a definition of financial literacy which accounting educators can use to underpin the design, delivery, and assessment of their programmes. 


\section{R. M. S. Wilson, A. Abraham and C. L. J. Mason}

\subsection{Defining financial literacy}

\subsubsection{Extending the notion of financial awareness}

In line with the discussion in Section 3.2 above, it is proposed here that the term literacy is synonymous with understanding or meaning-making, and that this meaning-making is a prerequisite for the achievement of desired outcomes or objectives. With financial literacy, these outcomes have financial consequences.

Financial literacy is generally understood to represent knowledge and understanding of financial concepts or products (Kotlikoff \& Bernheim, 2001; Hogarth et al., 2003; Lusardi \& Mitchell, 2011), with one of its most commonly accepted definitions being: 'the ability to make informed judgements and take effective decisions regarding the use and management of money' (Noctor et al., 1992). This restricted definition emphasises financial literacy as consisting of both objective knowledge on specific topics related to money, economics or financial matters, and also subjective measures of reported self-confidence (SEDI, 2005, p. 4).

In 2008, the American Institute of Certified Public Accountants (AICPA) defined financial literacy as being: 'the ability to effectively evaluate and manage one's finances in order to make prudent decisions toward reaching life goals and achieve financial wellbeing' (AICPA, 2008, p. 5). While projecting beyond the immediacy of a particular decision, this definition is limited in focussing specifically: on finances (rather than information relating to resources more generally); on households; and on ignoring differing degrees of risk aversion on the part of different decision-makers by its emphasis on prudence.

It is argued here that financial literacy is more than these deficient definitions suggest: it is a process leading to a desired outcome and should be more appropriately defined as: 'an individual's ability to obtain, understand and evaluate the relevant information necessary to make decisions with an awareness of the likely financial consequences' (Mason \& Wilson, 2001, p. 31). In other words, financial literacy is not in itself the desired outcome from decision-making, but rather the process of making meaning from contextual knowledge with the use of financial skills.

There is clearly a similarity here between information literacy and financial literacy. This is not surprising since information that has financial implications is still information. The difference between the two terms arises because the outcomes are different, with the latter term being relevant where the outcomes have financial consequences.

The above definition attempts to recognise that information relevant to decision-making may not necessarily be financial information in its strictest sense. For example, a school may face a reduced intake of pupils. This in itself is not financial information - though there are financial implications where a school's funding is determined by the number of pupils. The ability to recognise the financial implications of non-financial information is fundamental to financial literacy.

Informed decision-making is recognised as being necessary for achieving desired outcomes. It seems likely that the majority of these outcomes will follow on from a decision being made which is then followed by a course of action. It is hard to think of an example in which financial literacy is relevant where a decision is not implicit. Even in cases where people use financial information to ensure that their current behaviour is appropriate, ultimately a decision will be required over whether or not to continue with their current actions. For example, an individual looking at his/her current savings or pension provision will need to make a decision over whether to continue with his/her current strategy or whether to make alternative arrangements. Similarly, an individual within an organisation will also need to be able to obtain and understand relevant information to ensure that current or proposed actions are appropriate (i.e. goal congruent). 
It is important to note here that financial literacy can only ensure that individuals are informed to make decisions: it cannot ensure the 'right' decisions are actually made. This is because, inter alia, individuals do not always make decisions based purely on the basis of economic rationality. (See, for example, Wilson \& Zhang, 1997.)

In this definition, financial literacy is seen as being distinct from the achievement of desired outcomes resulting from decision-making processes. Differentiating literacy from the outcomes it enables is not to say, however, that achieving the desired outcomes is incidental to literacy. The outcomes give literacy its importance. If there were no desired outcomes to be achieved, then literacy in general, and financial literacy in particular, would be unimportant. To illustrate the point in terms of the conventional use of the term literacy, people read books for a purpose, such as for pleasure or to acquire knowledge. In order to achieve either of these outcomes, a person needs to be literate (that is, he/she makes use of a range of skills to read the book in order to understand it). Without this understanding the chances of achieving the desired outcomes are dramatically reduced. Furthermore, it is proposed that it is functionality which establishes the importance of financial literacy, and it is the outcomes which determine the value of financial literacy.

Financial literacy as defined in this chapter is a meaning-making process which enables informed decisions to be made in order to achieve desired outcomes as shown in Figure 3.2. In this model it is proposed that individuals use a combination of skills and technologies, resources, and contextual knowledge to make sense of information in order to be sufficiently informed to make decisions requiring an understanding of their financial consequences. These terms have been deliberately adopted as general descriptive terms. In addition, Figure 3.2 demonstrates that decisions are not made for their own sake, but to facilitate the attainment of desired outcomes.

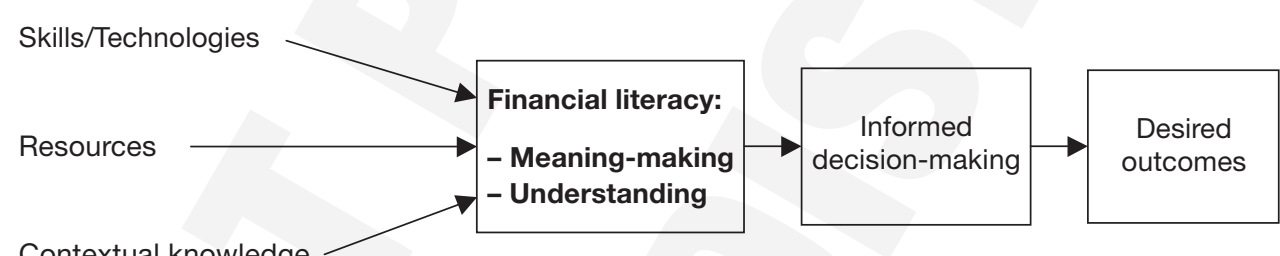

Figure 3.2 Financial literacy viewed as a meaning-making process

\subsubsection{Financial literacy studies}

Over the last decade and a half much has been written about the need to improve financial literacy, with studies having been carried out in a number of countries, but most especially in Australia, the U.K., and the U.S.A., in order to assess the general level of financial literacy in the community (e.g. Schagen \& Lines, 1996; NCEE, 2012; ANZ, 2003, 2005, 2008, 2011; ASIC, 2011; SEDI, 2005), or among specific cohorts (Beal \& Delpachitra, 2003; Bird, 2008; Chen \& Volpe, 1998). These studies have resulted in online programmes being developed by government, corporate, and not-for-profit sectors, as well as the development of programmes to embed financial literacy skills into school curricula. This sub-section reviews the major financial literacy studies that have been conducted in Australia, the U.K., and the U.S.A. in recent years, and presents the results in tabular format. (See Tables 3.1, 3.2, and 3.3.) It also provides an overview of the recent OECD pilot study into financial literacy in fourteen countries, and comments briefly on the effectiveness of the programmes, noting that there has been much less 
R. M. S. Wilson, A. Abraham and C. L. J. Mason

Table 3.1 Overview of major financial literacy studies in Australia

\begin{tabular}{ll}
\hline Study & Overview \\
\hline $\begin{array}{l}\text { ANZ (2011, 2008, 2005, } \\
\text { 2003) }\end{array}$ & $\begin{array}{l}\text { Aimed to capture the complexity of financial literacy through focussing } \\
\text { on behaviours indicative of a person's financial literacy and examining } \\
\text { the associations of those behaviours with people's demographic and } \\
\text { other characteristics, including attitudes to finances }\end{array}$ \\
$\begin{array}{l}\text { Commonwealth Bank } \\
\text { Foundation (CBF) (2004a, } \\
\text { 2004b) }\end{array}$ & $\begin{array}{l}\text { The first survey on financial literacy that investigated the strength of } \\
\text { any link between financial literacy and outcomes for individuals and } \\
\text { the Australian economy }\end{array}$ \\
$\begin{array}{l}\text { Citibank (Citi Australia, } \\
\text { 2010) }\end{array}$ & $\begin{array}{l}\text { Drew on the emerging field of behavioural economics to shed light on } \\
\text { why people do not behave as rationally as economics textbooks would } \\
\text { suggest }\end{array}$ \\
$\begin{array}{l}\text { National Australia Bank } \\
\text { (NAB) (Connolly et al., }\end{array}$ & $\begin{array}{l}\text { Building on NAB's ongoing interest in financial literacy since 2003, this } \\
\text { study measured the extent of financial exclusion as a result of a lack of } \\
\text { financial literacy, and the relationship this has with social and economic } \\
\text { disadvantage }\end{array}$ \\
\hline
\end{tabular}

emphasis on financial literacy in an organisational setting as opposed to the setting of households and individuals.

Between late 2010 and 2011, the OECD's International Gateway for Financial Education (IGFE) conducted a pilot study in fourteen countries across four continents. Data was collected by each participating country undertaking a nationally representative survey using a core questionnaire and providing the results of interviews with at least 1,000 individuals, which were then weighted to reflect the population of each country. Data analysis focussed on variations in financial knowledge, behaviour, and attitudes across the participant countries, and also within countries, by using socio-demographic indicators.

Atkinson \& Messy (2012) reported that the results highlighted a lack of financial awareness amongst a sizeable proportion of the population in each of the countries surveyed. The data also showed that attitudes to financial literacy varied widely. One particular concern was the relatively large proportion of people who could not calculate simple interest on a savings account over one year and then identify the impact of compounding over five years. Another was the lack of awareness of risk diversification benefits, with at least 33 per cent and in some countries more than 50 per cent of participants being unable to answer a question about this.

As might be expected, there was a consistently positive relationship between financial knowledge scores and financial behaviour scores, with participants having higher financial knowledge exhibiting more positive behaviours. The analysis on a socio-demographic basis indicated that, in all but one country, women had much lower levels of financial knowledge than men. For instance, in the U.K., a score of 6 or more for knowledge was obtained by 67 per cent of men but by only 40 per cent of women. The percentages were similar in Germany, being 67 per cent for men and 50 per cent for women. However, in most countries, women participants were more likely to have a more positive attitude towards the long-term perspective than their male peers. (For an international comparison among women, see The Times of India, 2011.)

Age and income provided other bases for variation in financial literacy. In most countries, the youngest and oldest respondents scored lower than those of middle age. Lower-income respondents were more likely to gain lower financial literacy scores than those in higher-income 
Table 3.2 Overview of major financial literacy studies in the U.K.

\begin{tabular}{|c|c|}
\hline Study & Overview \\
\hline Schagen \& Lines (1996) & $\begin{array}{l}\text { A financial literacy survey of the general population with a particular } \\
\text { focus on four groups: young people in work or training, students in } \\
\text { higher education living away from home, single parents, and families } \\
\text { living in subsidised housing. Results indicated that, in general, most } \\
\text { participants were confident in their financial dealings. Notable } \\
\text { exceptions were single parents who were less committed to saving, and } \\
\text { students who were the least confident group in dealing with financial } \\
\text { matters, with very few keeping any financial records. }\end{array}$ \\
\hline
\end{tabular}

Adult Financial Literacy Advisory Group (AdFLAG) (2000)

Financial Services Authority (PFRC, 2005)

Consumer Financial Education Body (Elliott et al., 2010)

Money Advice Service Board (Cl Research, 2012)
Concluded that the need for financial literacy would continue to grow because individuals are expected to become more self-reliant.

Recommended that short-term financial literacy education should be built around education, employment, housing, financial services and communication, with a particular focus on needy population sectors (such as older people, young people, sole parents, ethnic minorities, people with disabilities, and people living in social housing).

Considered the areas: 'managing money', 'planning ahead', 'choosing products', and 'staying informed'. Found that, while individuals may be particularly capable in one or more areas, they lacked skills or experiences in other areas. Recognised that it would take time for policies regarding financial education and the subsequent introduction of accounting education in this area to have an impact on the U.K. population.

Concluded that there is enormous scope to alter the environment in a way that encourages greater levels of financial capability, hence providing an opening for using accounting education as one such means of increasing these levels.

Found that current opinion varies among academics and experts in the field regarding the extent to which financial interventions produce positive outcomes. Evidence suggested that young people must be engaged in financial education from an early age.

brackets. There was also a positive relationship between education and financial literacy, with those who were more highly educated being likely to demonstrate both positive behaviours and attitudes. The report's authors concluded that:

The data holds a great deal of potential. We will continue with our analysis in order to inform the work of the INFE, focusing particularly on variations in financial literacy by key socio-demographic groups, levels of financial inclusion and financial access, as well as exploring in more detail the relationship between various aspects of financial literacy.

(Atkinson \& Messy, 2012, p. 12)

Furthermore, the results of the study will enable countries to identify needs and gaps in financial education provision in order to make progress in developing their own national policies or strategies. 
R. M. S. Wilson, A. Abraham and C. L. J. Mason

Table 3.3 Overview of major financial literacy studies in the U.S.A.

\begin{tabular}{ll}
\hline Study & Overview \\
\hline Mandell (1997), Huddleston-Casas & All studies investigated financial literacy levels among high \\
et al. (1999), Williams-Harold (1999), & school pupils and concluded that they showed a lack of \\
the National Council on Economic & both personal financial skills and knowledge
\end{tabular}

Education (from 1998 to 2012) and

the JumpStart Coalition (from 1997

to 2008)

Council for Economic Education

(CEE, 2012a, 2012b)

Concluded that the recent economic downturn following the GFC had brought nationwide attention to the dangers of a financially illiterate society, and that it was imperative to close the gap by providing educators with the knowledge, tools, and teaching skills they need to help individuals to develop essential real-world financial literacy skills

Results indicated that retail investors in the U.S.A. lacked basicfinancial literacy. They demonstrated a weak grasp of elementary financial concepts and lacked critical knowledge of methods to identify and avoid investment fraud.

This sub-section has provided a summary of the major studies that have been undertaken in financial literacy both nationally and internationally. Rather than taking an organisational perspective, most of these studies have focussed on the financial literacy of individuals or socioeconomic groups. In addressing the importance of financial literacy, the next sub-section provides an overview of various governmental and non-governmental financial literacy programmes that have been established across a wide range of countries.

\subsubsection{Why is financial literacy important?}

The authors' interest in financial literacy stems from a recognition that every individual in his/her domestic life, and every responsible manager, will be involved in decisions relating to the acquisition, allocation, and utilisation of resources, and that these processes inevitably have financial characteristics. In order to function in an effective manner, every citizen or manager needs to have a degree of financial literacy (whether as a user or a compiler of financial information). This is applicable in households, in (budget-constrained) public sector organisations, and in (profitseeking) private sector organisations, whether large or small, service-rendering, or manufacturing. Managers across any organisation need to be able to consider things using the same language, and the most appropriate lingua franca to facilitate cross-functional communication is usually one couched in financial terms. (See Turner, 2008.) To give an example, suitable skills are needed on the part of carers to ensure that financial abuse of the elderly can be identified and resolved (Gilhooly, 2012, p. 9). As a consequence, social care, health, and banking professionals need to have appropriate training to become sufficiently financially literate to enable them to handle this problem. 
Whether the focus is on the corporate sector or the personal sector, individuals can benefit from being financially literate by avoiding the need to defer to the specialist expertise of financial advisors. Henderson (2009b) referred to a study led by Gregory Berns at Emory University in the U.S.A. which suggested that financial advice can make people take leave of their senses because the brain sets rationality aside when it gets the benefit of supposedly expert opinion, thereby abdicating personal responsibility because of deference to the expert's authority.

Many examples of how this risk can be avoided are provided in both the corporate and personal sectors. With reference to the corporate sector, the Director of the Finance for Executives course at Oxford University's Said Business School, Alan Morrison, observed that:

Managers get to the stage where they are in charge of budgets, dealing with investors and deciding between conflicting uses of resources. They may not want to do the calculations themselves but they need to be able to have an informed discussion with [those] who do.

(Quoted in Lewis, 2008, p. 7)

An example of avoiding the risk in the personal sector occurred in 2007 when the Open University Business School in the U.K. offered for the first time its course entitled You and Your Money: Personal Finance in Context. This distance learning course aimed to help in developing practical financial skills as well as an understanding of the outside forces which affect personal finances and the jargon that surrounds them.

There is a noticeable lack of literature concerned with the financial literacy of managers within organisations, despite the proliferation of textbooks and short courses with titles such as Finance for the Non-Financial Manager. This widely-used label is itself misleading because 'finance' (which is concerned with the acquisition, allocation, and utilisation of funds) is quite distinct from 'accounting' (which is concerned with flows of information - largely but not exclusively of a financial nature - to help in planning, decision-making, and control). There is, however, a great deal of literature on the financial literacy of private individuals.

\subsubsection{Attempts to address financial literacy}

Much of the interest shown in financial literacy stems from a concern over people's lack of financial literacy. This is particularly true when individuals are viewed as consumers of financial products. Concern has been expressed over many years about the ability of these consumers to make effective decisions (e.g. Schagen \& Lines, 1996; Jennings et al., 1997). The evidence suggests that available information is used ineffectively, if at all, in consumer decision-making about financial products.

This concern, which is recognised internationally, is exemplified at the personal and household levels by the existence of bodies such as:

- the Financial Services Authority's national strategy on financial capability (which was launched in the U.K. in 2003 - see FSA 1998, 1999, 2006). (The FSA was replaced in 2013 by the Financial Conduct Authority, which is concerned with consumers' interests, and the Prudential Regulation Authority, which oversees the banking system.)

- $\quad$ the Financial Literacy Centre at the University of Warwick (U.K.);

- the Financial Literacy Foundation (Australia);

- the National Endowment for Financial Education (U.S.A.);

- the Financial Literacy Center (U.S.A.) (See U.S. Financial Literacy and Education Commission, 2006.) 


\section{R. M. S. Wilson, A. Abraham and C. L. J. Mason}

It is also evidenced by the development of programmes such as:

- the Start Right Coalition for Financial Literacy (Canada);

- the Jump\$tart Coalition for Personal Financial Literacy (U.S.A.);

- the OECD's International Gateway for Financial Education (see OECD, 2005, 2008, 2012);

- the Commonwealth Bank Foundation (Australia) which aims to encourage the development of financial education programmes primarily targeted on young people; and

- the U.K.'s Money Advice Service which, since 2011, has been involved in a number of projects aimed at raising the financial literacy/capability of consumers, which is the same target as most other government-sponsored programmes (including the Australian government's Money Management programme). A recent review of the Money Advice Service suggests that it is not achieving what was expected of it (see Hosking, 2013).

The Australian government established a Consumer and Financial Literacy Taskforce to develop the National Strategy for Consumer and Financial Literacy which aimed to develop a national strategy to reduce poverty, increase economic opportunity, support national savings, and create well-informed consumers. On an international basis, as briefly mentioned above, the OECD's International Gateway for Financial Education (IGFE) provides a policy forum for governments to exchange views and experiences around the issue of financial education. To this end, it has established an international online database, the IGFE, which 'serves as a global clearinghouse on financial education, providing access to a comprehensive range of information, data, resources, research and news on financial education issues and programmes around the globe' (OECD, 2012).

One of the most recent attempts to address financial literacy by raising the level of financial capability in the U.K. was through the establishment of the Pathfinder Money Guidance service by the FSA in March 2009. Three channels were used to provide services in the two regions (North-West England and North-East England) in which Pathfinder was initially piloted. These channels consisted of a website, a telephone helpline, and a face-to-face information and guidance service. During its first year of operation, it was concluded that the programme 'largely achieved one of its key aims of reaching people who are potentially vulnerable to the consequences of poor financial decision making' (Kempson et al., 2010, p. 4). It is estimated to have delivered 570,000 Money Guidance sessions to 220,660 individuals. The website was the most used channel (with 192,250 individual users), followed by the face-to-face sessions $(24,595)$, and then the telephone helpline $(3,811)$. This was not what the designers had expected: they had anticipated that the website would be the most used medium, and expected that the telephone service would be more popular than the face-to-face medium. While no reason for this was suggested, it could be hypothesised that those with lower financial literacy levels may find that the face-to-face service allowed them to be able to see plans mapped out on paper rather than having to write information down for themselves from a telephone session, or maybe these face-to-face sessions facilitated their 'meaning-making' more effectively

Similar programmes include:

- In Australia, the Federal Government provides an online website for its National Financial Literacy Strategy (NFLS) which identifies various programmes across a range of sectors: community, indigenous, government, workplace, and international (ASIC, 2012). These include interactive school education programmes, community forums providing investment and banking advice, a matched savings programme aiming to increase personal savings and financial capability of people on low incomes, and workplace financial education programmes targeted at different demographic groups. 
- The leading organisation that provides financial literacy education in the U.S.A. is the Council for Economic Education (CEE). It specifically focuses on the economic and financial education of pupils from kindergarten through to the end of secondary school with the aim of assisting children to grow into successful and productive adults who are capable of making informed and responsible decisions. To this end, it provides professional development for teachers, and develops teaching resources for use across the curriculum. Its programmes are delivered in face-to-face workshops, through partner organisations, and online (CEE, 2012a).

- In a similar way there have been pressures over many years for financial literacy to be taught in U.K. schools to counteract what has been described as financial illiteracy on the part of both younger children (see Sugden, 2009; Grimston, 2010a) and teenagers (see Bennett, 2008). For example, an initiative in 2006 by the Institute of Chartered Accountants in England \& Wales (ICAEW) and others to establish a data-base of experts who could help schools in providing a practical understanding of financial matters - including how to make informed financial decisions - was to be based on the experts tutoring the teachers, with the latter then dealing with the pupils. (See Accountancy Age, 17 August 2006, p. 10, and http://www.barclaysmoneyskills.com).

- In New Zealand, the Financial Education and Research Centre was founded by Massey University and Westpac New Zealand to improve New Zealanders' knowledge, attitudes, and behaviour towards money matters by addressing the quality of and access to education on personal finance, and identifying knowledge gaps and how these can be bridged. Key projects include a 20-year longitudinal study that will follow up to $300 \mathrm{New}$ Zealanders to understand their needs for financial knowledge at different life stages, a multi-level certification programme for personal financial educators, and the New Zealand Retirement Expenditure Survey - a joint initiative between the centre and the savings industry body Workplace Savings NZ - which aims to establish guidelines for 'modest' and 'comfortable' retirement. (See Strangl \& Matthews, 2012.)

- In Australia, the Money Smart Teaching website (www.teaching.moneysmart.gov.au) provides resources to help in integrating financial literacy into schools.

- Across the European Union there are online resources to assist teachers with delivering financial literacy classes (as part of the Dolceta programme: see www.dolceta.eu); and the OECD's International Gateway for Financial Education does a similar thing on a worldwide basis.

- In the U.S.A., the Financial Literacy Center (which was established in October 2009 by the RAND Corporation, the Wharton School of the University of Pennsylvania, and Dartmouth College) has developed educational tools and programmes to improve financial literacy and promote informed financial decision-making (www.rand.org/labor/centers/ financial-literacy).

Once again, the focus of all the above initiatives tends to be on financial literacy for personal rather than organisational decision-making. However, a novel variation is the International Certificate in Financial English set up by the University of Cambridge and the ACCA. This aims to cater for those working in international finance on a global basis by providing high levels of English language (rather than financial) skills which are relevant to this fast-moving field in order to boost the international mobility of young accountants.

Another variation on the theme comes from the Chartered Institute of Management Accountants (CIMA) which now offers certificates and a diploma in Islamic Finance 'to provide 


\section{R. M. S. Wilson, A. Abraham and C. L. J. Mason}

the skills and knowledge needed to exploit the global shortage of qualified Islamic finance professionals'. (See Financial Management, December 2012, p. 40.)

In 2007, the then U.K. government announced that, from 2008, a new subject (Economic Well-Being and Financial Capability) would be introduced into the curriculum of secondary schools, aiming to help school leavers cope better with life after school (see Bennett, 2007; Purves, 2007; Grimston, 2010a). However, critics objected to its inclusion in the Mathematics curriculum, thereby detracting from mathematics without having the substance to ensure financially-informed decision-making (see Woolcock, 2008). It is a powerful argument that young people's primary and secondary education should ensure that they emerge from school with adequate literacy and numeracy skills to subsequently become financially literate, since those who are only semi-literate or innumerate when they leave school are unlikely - as adults - to remedy the deficiencies in their education or, as a consequence, to become financially literate.

Despite all the above initiatives, it is significant - and disappointing - that such academic assessments of financial education as have been undertaken do not offer evidence of measurable success in improving participants' financial well-being. See, for example, Cole \& Shastry (2008), and Willis (2009).

Despite the level of activity revolving around financial literacy, there does not appear to be any published material attempting to characterise a financially literate person. Advice is offered to those who are considered financially illiterate, yet what makes one person financially literate and the next person not? Centres dedicated to financial literacy aim to improve individuals' financial literacy because there is evidence that many individuals make poor use of financial information and this is blamed on financial illiteracy - which brings us back to questions such as:

- What does this actually mean?

- In what way are these individuals failing to use available information effectively?

- What do they not understand?

- Why do they not understand it?

- Do they not understand it or do they simply not make good use of it?

- Is the information presented in a way which is unhelpful?

- Do the individuals lack the necessary skills to analyse and interpret the information?

- Do they use other sources of information (e.g. the advice of friends and family) in lieu of making their own reasoned decisions?

These questions and many others remain unanswered.

\subsection{Implications and conclusion}

In this chapter it has been argued that financial literacy can be seen to have considerable importance - whether in the context of households or in the setting of more formal organisations. To some degree this 'self-evident' importance has resulted in surprisingly little attention being devoted to developing an adequate definition of financial literacy, with the focus instead being devoted to encouraging individuals to become financially aware (i.e. focussing on skills rather than on meaning-making). This is not the same as being financially literate, so the situation is clearly problematic, and applies as much in the domain of accounting education as elsewhere.

In discussing literacy and numeracy more generally, along with the non-trivial problems of illiteracy and innumeracy, the important roles of meaning-making and learning were introduced as being vital aspects of gaining an understanding of what is going on in one's field of activity. 
When this was extended to financial awareness, we argued that the level of understanding of financial matters needed in order for an individual to be deemed financially aware does not render an individual financially literate. The latter presupposes the former, plus insights into the ways in which financial awareness can be used in the decision-making process to achieve desired outcomes with an understanding of their likely financial consequences.

At several points in the chapter there has been an emphasis on context, and a number of ways in which accounting educators might use financial literacy as a cornerstone of their programmes can be suggested, based on a concern for context. We could teach accounting techniques from dawn to dusk, but this would be of limited value if devoid of context. Accounting numbers are surrogates which represent events, activities and outcomes - but meaning can only be attributed to them when one knows the context to which the numbers refer. We will look at two possible ways of using financial literacy as a point of reference for accounting educators. These focus on the derived nature of financial literacy, on the one hand, and on key managerial questions, on the other.

Taking the first of these, one can argue with some conviction that the outputs from accounting systems help facilitate planning, decision-making, and control - whether in relation, say, to an individual's affairs, those of a small charity, those of a university, or those of a multinational corporation. However, this is not to suggest that accounting information is desired for its own sake. The demand for such information, from a financial literacy perspective, is to help individuals to make meaning and to develop a narrative in order to understand what is happening around them, and then using this understanding to make purposive decisions with a reasonable insight into the likely financial consequences of those decisions. In other words, the demand for accounting information is of a derived nature.

This is clearly illustrated in Figure 3.2. The sequence, with its first-order and second-order effects, was also evident in a novel definition of managerial accounting offered by Wilson \& Chua (1993, p. 16), which extended previous definitions by emphasising the derived nature of information generated by managerial accounting systems (MAS):

Managerial accounting encompasses techniques and processes that are intended to provide financial and non-financial information to people within an organization [to enable them] to make better decisions and thereby achieve organizational control and enhance organizational effectiveness.

This can be illustrated as shown (ibid., p. 424):

\begin{tabular}{|c|c|c|c|c|}
\hline $\begin{array}{l}\text { Managerial } \\
\text { accounting }\end{array}$ & LEADS TO & $\begin{array}{l}\text { Satisfaction of people's } \\
\text { need for information } \\
\text { for decision-making }\end{array}$ & LEADS TO & $\begin{array}{c}\text { Organizational } \\
\text { control and } \\
\text { effectiveness }\end{array}$ \\
\hline
\end{tabular}

A crucial element in this definition is the notion of organisational control, which focuses on the process of ensuring that an organisation pursues courses of action which seek to achieve its aims. The organisation can be deemed to be effective to the extent that it is successful in this endeavour. To this end, those who design, implement, and operate MAS need to recognise the social processes by which people attach meaning to managerial accounting information in order to make sense of the context in which they are seeking to make effective decisions. In other words, both compilers and users of accounting information need to be financially literate - and accounting educators need to be mindful of this when designing curricula, pedagogic approaches for delivery, and assessment strategies for their programmes. 
R. M. S. Wilson, A. Abraham and C. L. J. Mason

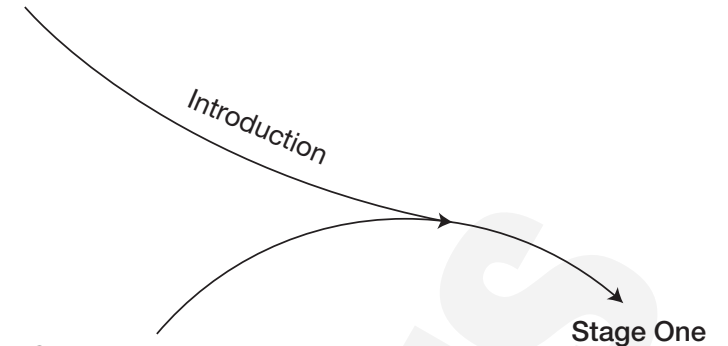

Stage Five

How can we ensure arrival? (Control)

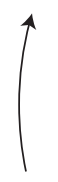

Stage Four Which way is best? (Evaluation)

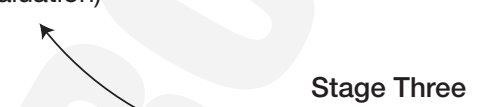
How might we get there? (Means)
Where are we now? (Beginning)

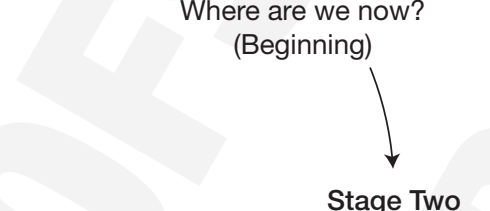

Where do we Two

here do we want to be?

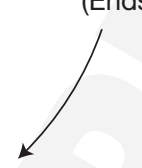

\section{Figure 3.3 Key managerial questions}

The second contextual possibility relates to key managerial questions, which are illustrated in Figure 3.3 (Wilson \& Gilligan, 2005, p. 8). This logical sequence of questions, which requires re-iteration on a continuous basis to reflect the dynamics of a changing world, represent planning (Q 1 and Q 2), decision-making (Q 3 and Q 4), and control (Q 5). The questions are:

1 Where are we now? This raises the question of where the organisation is now in terms of such factors as its competitive position, financial performance, and product range. Published financial reports can provide some insights (subject to their inherent limitations), as can activity-based costing reports showing where resources were consumed in the recent past (e.g. by product, process, market segment, distribution channel, etc.), and with what consequences (e.g. by segmental profit statements and productivity reports).

2 Where do we want to be? This refers to the specification of aims (or desired outcomes), which may not be explicitly framed in financial terms, but the attainment of which will inevitably entail the consumption of resources which have a cost, and usually the requirement to generate revenue and either a profit or a surplus.

3 How might we get there? This is concerned with the identification of possible means by which desired ends might be achieved, and their likely financial characteristics.

4 Which way is best? Having to choose among the competing alternatives identified in stage 3 in the face of resource constraints is central to decision-making, and requires attention to be paid to aspects of risk and the time-frame (i.e. short-term or long-term) in judging the relative attractiveness of competing alternatives. An array of accounting techniques is available for addressing this question, but the right one has to be chosen to fit the circumstances. 
5 How can we ensure arrival? This relates to the effective implementation of the chosen course(s) of action from stage 4. Monitoring performance is necessary in order that corrective action (as necessary) may be taken, and again there is an array of accounting techniques which can help in this challenge.

While the above questions are unambiguously managerial, there are characteristics of each which require that those involved in addressing them are financially literate. Financial literacy leads to informed decision-making, and informed decision-making is more likely to result in desired outcomes.

The key messages for accounting educators from this chapter are that they should:

- Be precise in distinguishing between financial awareness (i.e. what do you know?) and financial literacy (i.e. how can what you know be used to bring about desired outcomes?).

- Present financial reports (of whatever type) as inputs into a broader process involving a need for understanding (via meaning-making) on the part of both compilers and users within a particular context (whether domestic, corporate, or other).

- Recognise that technical accounting skills are necessary but not sufficient for accounting students/trainees/practitioners to be deemed financially literate.

- Accept that meaning-making (which is so central to understanding) is an individual matter, within differing social and cultural settings.

The development of narratives based on the meaning which one makes gives a basis for learning, and learning is of critical importance since it embraces:

- $\quad$ using one's understanding to explain what's going on in the present;

- $\quad$ using one's understanding of the present to make more accurate predictions of the future;

- basing one's decisions on the predictions derived from understanding;

- $\quad$ using one's understanding to control the outcomes from those decisions; and

- learning in order that one might do things better next time.

In sum, accounting educators need to ensure that the Accounting curriculum is designed, delivered, and assessed in ways which show Accounting in its personal, organisational, and societal contexts (e.g. relating to processes such as planning, decision-making, and control) if future users and compilers of financial information are to exhibit financial literacy.

\section{References}

Adult Financial Literacy Advisory Group (AdFLAG) (2000) Report to the Secretary of State for Education and Employment, Department of Education and Skills, London. Available at: http://www.dfes.gov.uk/adflag/ (accessed 10 September 2005).

American Institute of Certified Public Accountants (AICPA) (2008) Financial literacy: knowing what you need to know to achieve your financial goals. Available: http://aicpa.org/download/financialliteracy/ financial_literacy_toolkit/financial_literacy_power_point_10-8-8.ppt (accessed 30 May 2009).

American Library Association's Presidential Committee on Information Literacy (1989) Final Report: 1989, Chicago: American Library Association.

Anonymous (2008) The kids aren't all right: functionally illiterate and frankly not bothered, Times Higher Education, 21, February, pp. 26-27.

ANZ (2003) National Survey of Adult Financial Literacy, Melbourne: ANZ and Roy Morgan Research, May. ANZ (2005) ANZ Survey of Adult Financial Literacy in Australia, Melbourne: ANZ and AC Nielson, November. 


\section{R. M. S. Wilson, A. Abraham and C. L. J. Mason}

ANZ (2008) ANZ Survey of Adult Financial Literacy in Australia, Melbourne: ANZ and The Social Research Centre, October.

ANZ (2011) Adult Financial Literacy in Australia, Melbourne: ANZ and The Social Research Centre, November.

ASIC (2011) Financial Literacy and Behavioural Change, Canberra: Australian Government, March.

ASIC (2012) National Financial Literacy Strategy, available at: http://www.financialliteracy.gov.au/otherprograms-and-resources (accessed 20 October 2012).

Association of Chartered Certified Accountants (2012a) Reassessing the Value of Corporate Reporting, London: ACCA.

Association of Chartered Certified Accountants (2012b) Closing the Value Gap: Understanding the Accountancy Profession in the 21st Century, London: ACCA.

Atewill, F. (2010) One million Londoners cannot read, Metro, 19 July, p. 12.

Atkinson, A. \& Messy, F. (2012) Measuring financial literacy: results of the OECD/International Network on Financial Education (INFE) Pilot Study, OECD Working Papers on Finance, Insurance and Private Pensions, No. 15, OECD Publishing. doi: 10.1787/5k9csfs90fr4-en.

Barrow, M. (2012) Doctors' orders too complicated for most patients, The Times, 7 December, p. 23.

Bartlett, S.A. \& Chandler, R.A. (1997) The corporate report and the private shareholder: Lee and Tweedie twenty years on, British Accounting Review, 29, 245-261.

Beal, D.J. \& Delpachitra, S.B. (2003) Financial literacy among Australian university students, Economic Papers, 22(1), 65-78.

Beal, T. (2009) Biblical Literacy, London: HarperOne.

Bennett, R. (2007) Children to get lessons in money - and debt, The Times, 9 July, pp. 1-2.

Bennett, R. (2008) Clueless generation need to do the maths, The Times, 10 March, p. 29.

Berger, P.L. \& Luckmann, T. (1966) The Social Construction of Reality, Garden City, NJ: Doubleday.

Bianculli, D (1992). Teleliteracy, New York: Continuum.

Bird, S. (2008) Financial literacy among university students: an Australian case study, unpublished Master's dissertation, University of Wollongong, Australia.

Birkhead, T. (2006) Riting good is a tuff choar, innit? Times Higher Education, 9 June, p. 62.

Blair, A., Coulombeau, S., \& Brown, O. (2004) University students not as clever as they used to be, The Times, 10 August, p. 7

Boland, R.J. (1980) Organizational sense making and alternative accounting systems: a case analysis, paper presented at the Annual Meeting of the Academy of Management, Detroit, 11-13 August.

Boland, R.J. (1984) Sense-making of accounting data as a technique of organizational diagnosis, Management Science, 30(7), 868-882.

Boland, R.J. (1987) The in-formation of information systems, in Boland, R. \& Hirscheim, R. (eds) Critical Issues in Information Systems Research, Chichester: Wiley, pp. 363-381.

Brooks, M. (2007) Heroes and zeros, Financial Management, October, p. 12.

Buchanan, R. (2013) Cleverest maths pupils 'fall behind children in Far East', The Times, 22 February, p. 20.

Budworth, D. (2012) The maths skills that everyone should have, The Times, 10 November, p. 60.

Burnet, M. (1965) Abc of Literacy, Paris: United Nations.

Cafferkey, K. \& Doyle, G. (2011) Health literacy and economic costs, paper presented at the Irish Accounting \& Finance Association Annual Conference, 2011.

Chen, H. \& Volpe, R.P. (1998) An analysis of personal financial literacy among college students, Financial Services Review, 7(2), 107-128.

Cheuk, B. (2002) Using Sense-Making to Study Information Seeking and Use in the Workplace. Available at: http://communication.sbs.ohio-state.edu/sense-making/inst/instcheuk02workplace.html (accessed 11 December 2012).

CI Research (2012) Impact Review of Financial Education for Young People: A Summary Report for the Money Advice Service, Wilmslow, Cheshire: author.

Citi Australia (2010) Evidence Versus Emotion: How Do We Really Make Financial Decisions? Canberra: Citi Australia and The Australia Institute.

Cole, S. \& Shastry, G.K. (2008) If you are so smart, why aren't you rich? The effects of education, financial literacy and cognitive ability on financial market participation, Harvard Business School Working Paper 09-071. Available at http://www.afi.es/EO/FinancialLiteracy.pdf (accessed 12 December 2012).

Commonwealth Bank Foundation (CBF) (2004a) Australians and Financial Literacy, Sydney: Commonwealth Bank Foundation. 
Commonwealth Bank Foundation (CBF) (2004b) Improving Financial Literacy in Australia: Benefits for the Individual and the Nation, Research Report, Sydney: Commonwealth Bank Foundation.

Connolly, C., Georgouras, M., Hems, L., \& Wolfson, L. (2011) Measuring Financial Exclusion in Australia, Sydney: Centre for Social Impact (CSI) - University of New South Wales for National Australia Bank. Cook-Gumperz, J. (ed.) (1986) The Social Construction of Literacy, Cambridge: Cambridge University Press.

Council for Economic Education (CEE) (2012a) All resources. Available at: http://www.councilfor econed.org/resources/ (accessed 20 October 2012).

Council for Economic Education (CEE) (2012b) Council for Economic Education's survey of the states reveals slow progress in economic and personal finance education implementation, Press Release, 12 March, New York. Available at: http://www.councilforeconed.org/news-information/survey-of-thestates/ (accessed 20 October 2012).

Craver, K.W. (1997) Teaching Electronic Literacy: A Concepts-Based Approach for Library Media Specialists, Westport, CT: Greenwood Press.

Cree, A., Kay, A., \& Steward, J. (2012) The Economic and Social Costs of Illiteracy: A Snapshot in a Global Context, Melbourne: World Literacy Foundation.

Day, J.M. (1987) Computer Literacy and Library and Information Studies: A Literature Review, British Library Research Paper No. 18, London: British Library.

Eaton, J. \& Bawden, D. (1991) What kind of resource is information? International Journal of Information Management, 11, 156-165.

Elliott, A., Dolan, P., Vlaev, I., Adriaenssens, C., \& Metcalfe, R. (2010) Transforming Financial Behaviour: Developing Interventions That Build Financial Capability, Consumer Research Report CR01, London: Consumer Financial Education Body (CFEB).

Fast Futures Research (2012) 100 Drivers of Change for the Global Accountancy Profession, London: ACCA's Accountancy Futures Academy.

Financial Services Authority (1998) Promoting public understanding of financial services: a strategy for consumer education, November, Consultation Paper No. 15, London: FSA.

Financial Services Authority (1999) Consumer Education: A Strategy for Promoting Public Understanding of the Financial System, London: FSA.

Financial Services Authority (2006) Financial Capability in the UK: Delivering Change, London: FSA Available at: http://www.fsa.gov.uk/pubs/other/fincap_delivering.pdf (accessed 12 December 2012).

Frean, A. (2007) Students have to learn basic maths at university, The Times, 25 April, p. 27.

Frean, A. (2008) Adults struggling with the sum total of life, The Times, 3 March, p. 25.

Frean, A., Yobbo, Y., \& Duncan, I. (2007) A-level students unable to write essays, The Times, 15 August, p. 9.

Furnham, A. (2011) In some parts of business psychopaths are the norm, The Sunday Times, 8 May, p. 72.

Gee, J. (1990) Socio Linguistics and Literacies, Basingstoke: Falmer Press.

Gilhooly, M. (2012) Financially safeguarding the elderly, Society Now, Issue 14, Autumn, p. 9.

Grimston, J. (2010a) Pupils to be given lessons on debt, The Sunday Times, 3 January, p. 6.

Grimston, J. (2010b) Top firms forced to reject 'barely literate' graduates, The Times, 1 August, p. 6.

Gross, M. (2010) So Why Can't They Read? London: Centre for Policy Studies.

Haack, D.G. (1979) Statistical Literacy: A Guide to Interpretation, North Scituate, MA: Duxberry Press.

Hanushek, E.A. \& Peterson, P.E. (2011) Why can't American students compete with the rest of the world? Newsweek, 5 September, 158(10), 42-45.

Henderson, M. (2009a) Probability lessons may teach children how to weigh life's odds and be winners, The Times, 5 January, pp. 14-15.

Henderson, M. (2009b) Brain's critical opt-out makes us suckers for a hard sell, The Times, 24 March, p. 17.

Hepworth, M. \& Walton, G. (2009) Teaching Information Literacy for Inquiry-Based Learning, London: Chandos Publishing.

Hofsteter, F.T. (1995) Multi-media Literacy, New York: McGraw-Hill.

Hogarth, J., Beverly, S.G., \& Hilgert, M. (2003) Patterns of financial behaviors: implications for community educators and policymakers, paper presented at Federal Reserve System Community Affairs Research Conference, February, pp. 1-22.

Hoggart, R. (1957) The Uses of Literacy, London: Chatto \& Windus.

Hopkins, K. \& Clark, A. (2011) Concern over statisticians who keep getting numbers wrong, The Times, 15 August, p. 36. 


\section{R. M. S. Wilson, A. Abraham and C. L. J. Mason}

Hosking, P. (2013) Debt advice service a waste of money, say furious MPs, The Times, 3 December, p. 45. Huddleston-Casas, C.A., Danes, S.M., \& Boyce, L.M. (1999) Impact evaluation of a financial literacy program: evidence for needed educational policy changes, Consumer Interests Annual, Vol. 45, pp. 109-114. Hurst, G. (2013) Anxious UK pupils lag behind in maths, The Times, 4 December, p. 12.

Institute of Education (1983) Teaching Political Literacy: Implications for Teacher Training and Curriculum Planning, London: University of London, Institute of Education, Paper 16.

Jackson, M. (1993) Literacy, London: David Fulton Publishers.

Jackson, S. \& Durkee, D. (2008) Incorporating information literacy into the accounting curriculum, Accounting Education: an international journal, 17(1), 83-97.

Jennings, M., Nelson. E., \& Boucher, A. (1997) Financial literacy: the cost of ignorance, RSA Journal, March, 31-35.

Kempson, E., Collard, S., Finney, A., Atkinson, A., Davies, S., \& Hayes, D. (2010) Money Guidance Pathfinder: A Report to the FSA, Evaluation Report ER01, Bristol: Personal Finance Research Centre, University of Bristol.

King, J. (2010) Thunderer, The Times, 22 February, p. 24

Kotlikoff, L.J. \& Bernheim, B. (2001) Household financial planning and financial literacy, in Kotlikoff, L.J. (ed.) Essays on Saving, Bequests, Altruism, and Lifecycle Planning, Cambridge, MA: MIT Press.

Kulthau, C.C. (1991) Introduction, in Varlejs, J. (ed.) Information Literacy: Learning How to Learn, Proceedings of the Twenty-eighth Annual Symposium of the Graduate Alumni and Faculty of the Rutgers School of Communication, Information and Library Studies, 6 April 1990, Jefferson, NC: McFarland \& Company.

Layton, D. (1994) Scientific and Technological Literacy: Meanings and Rationales: An Annotated Bibliography, Leeds: Centre for Studies in Science and Mathematics Education, University of Leeds in association with UNESCO.

Lee, T.A. \& Tweedie, D.P. (1975a) Accounting information: an investigation of private shareholder usage, Accounting and Business Research, 20, Autumn, 280-291.

Lee, T.A. \& Tweedie, D.P. (1975b) Accounting information: an investigation of private shareholder understanding, Accounting and Business Research, 21, Winter, 3-17.

Lee, T.A. \& Tweedie, D.P. (1976) The private shareholder: his sources of financial information and his understanding of reporting practices, Accounting and Business Research, 24, Autumn, 304-314.

Lee, T.A. \& Tweedie, D.P. (1977) The Private Shareholder and the Corporate Report, London: ICAEW.

Lewis, C. (2008) Master the money and the rest falls into place, The Times, 21 February, p. 7.

Lusardi, A. \& Mitchell, O.S. (2011) Financial literacy around the world: an overview, Journal of Pension Economics and Finance, 10(4), 497-508.

MacInnes, J. (2013) Sexy statistics? Society Now, Autumn, pp. 16-17.

Maitlis, S. (2005) The social processes of organizational sense-making, Academy of Management Journal, 48(1), 21-49.

Maitlis, S. \& Lawrence, T. (2007) Triggers and enablers of sense-giving in organizations, Academy of Management Journal, 50(1), 57-84.

Mandell, L. (1997) Personal Financial Survey of High School Seniors, Jump Start Coalition for Personal Financial Literacy, March/April. Washington, DC.

Marriott, D.N. \& Mellett, H.J. (1991) The Financial Awareness of Managers in the Reformed NHS, Occasional Research Paper No. 10, London: ACCA.

Marriott, D.N. \& Mellett, H.J. (1994) Resources, Responsibility and Understanding in the NHS, Research Report No. 37, London: ACCA.

Marriott, D.N. \& Mellett, H.J. (1995) The level of financial skills of National Health Service managers, Financial Accountability \& Management, 11(3), 271-282.

Marriott, D.N. \& Mellett, H.J. (1996) Health care managers' financial skills: measurement, analysis and implications, Accounting Education: An international journal, 5(1), 61-74.

Martin, L.H.M. (ed.) (1997) The Challenge of Internet Literacy: The Instruction-Web Convergence, New York: Haworth Press.

Mason, C.L.J. \& Wilson, R.M.S. (2001) Conceptualising financial literacy, paper presented at the Annual Conference of the British Accounting Association, University of Nottingham, 26-28 March.

Milner, M.M. \& Wan Ying Hill (2008) Support for graphicacy: a review of textbooks available to accounting students, Accounting Education: an international journal, 17(2), 173-185.

Moynihan, J. (2012) \$135-\$12 = the pay gap the West can't bridge, The Times, 15 August, p. 17.

Mutch, A. (1997) Information literacy: an exploration, International Journal of Information Management, 17(5), 377-386. 
National Council on Economic Education (NCEE) (2012) Survey of the States: Economic and Personal Finance Education in Our Nation's Schools in 2011, New York: National Council on Economic Education.

Noctor, M., Stoney, S., \& Stradling, R. (1992) Financial Literacy: A Discussion of Concepts and Competences of Financial Literacy and Opportunities for its Introduction into Young People's Learning, report prepared for the National Westminster Bank, National Foundation for Education Research, London.

Oppenheim, C., Stenson, J.A., \& Wilson, R.M.S. (2003a) Studies in information as an asset - I, Journal of Information Science, 29(3), 159-166.

Oppenheim, C., Stenson, J.A., \& Wilson, R.M.S. (2003b) Studies in information as an asset - II, Journal of Information Science, 29(5), 419-432.

Oppenheim, C., Stenson, J.A., \& Wilson. R.M.S. (2004) Studies in information as an asset - III, Journal of Information Science, 30(2), 181-190.

Organisation for Economic Co-operation \& Development (OECD) (2005) Improving Financial Literacy: Analysis of Issues and Policies, Paris: OECD.

Organisation for Economic Co-operation and Development (OECD) (2008) International Gateway for Financial Education, Paris: OECD. Available at: http://www.financial-education.org (accessed 12 December 2012.)

Organisation for Economic Co-operation \& Development OECD) (2012) International Gateway for Financial Education. Available at: http://www.financial-education.org/home.html (accessed 20 October 2012).

Oxenham, J. (1980) Literacy: Writing, Reading and Social Organisation, London: Routledge \& Kegan Paul.

Pank, P. (2012) West Coast franchise inquest exposes a 'first-class fiasco', The Times, 7 December, pp. $14-15$.

Peel M.J. \& Pendlebury M. (1998) Employee Share Ownership and Financial Awareness: Some Further Evidence, ACCA Research Report No. 24, London: ACCA.

Peel, M.J., Pendlebury, M.W., \& Groves, R.E.V. (1991) Employee Share Ownership, 'Financial Awareness' and the Reporting of Financial Information to Employees, ACCA Research Report No. 22. London: ACCA

Personal Finance Research Centre (PFRC) (2005) Measuring Financial Capability: An Exploratory Study, report prepared for the Financial Services Authority (FSA) by Personal Finance Research Centre, University of Bristol.

Peterson, P.E., Woessmann, L., Hanushek, E.A., \& Lastra-Anadón, C.X. (2011) Are U.S. students ready to compete? The latest on each state's international standing, Education Next, 11(4), 51-59.

Purves, L. (2007). What we want is facts. Financial facts, The Times, 10 July, p. 15.

Saunders, J. (2010) Foreigners flock to academic-literacy lessons, Times Higher Education, 18 February, p. 11.

Schagen, S. \& Lines, A. (1996) Financial Literacy in Adult Life: A Report to the NatWest Group Charitable Trust, Slough, Berkshire: National Foundation for Educational Research.

Schuman, P.G. (1991) Introduction, in Varlejs, J. (ed.) Information Literacy: Learning How to Learn, Proceedings of the Twenty-eighth Annual Symposium of the Graduate Alumni and Faculty of the Rutgers School of Communication, Information and Library Studies, 6 April 1990, Jefferson, NC: McFarland \& Company.

Securities and Exchange Commission (SEC) (2012) Study Regarding Financial Literacy Among Investors, New York: U.S. Securities and Exchange Commission.

SEDI (2005) Why Financial Capability Matters, Synthesis Report on Canadians and Their Money: A National Symposium on Financial Capability, Ottawa: Canadian Government.

Sorensen, K., Van Den Brouke, S., Fullam, J., Doyle, G., Pelikan, J., Slonska, Z., \& Brown, H. (2012) Health literacy and public health: a systematic review and integration of definitions and models, $B M C$ Public Health, 12.80. doi: 10.1186/1471-2458-12-80.

Stibbe, A. (ed.) (2009) Handbook of Sustainability Literacy: Skills for a Changing World, Totnes: Green Books.

Strangl, J. \& Matthews, C. (2012) How Young New Zealanders Learn About Personal Finance: A Longitudinal Study, Financial Education and Research Centre, November, Wellington, NZ: Massey University.

Street-Porter, J. (2009) If kids can't read or count, how do they get a job? The Independent on Sunday, 29 November, p. 21.

Sugden, J. (2009) Schools call in bankers to teach maths to the credit crunch class, The Times, 14 September, p. 17.

Sugden, J. (2011) Make maths compulsory for all until 18, The Times, 8 August, p. 8

Taylor Nelson Financial (1992) Financial Quiz Summary Report, London: Taylor Nelson.

The Sunday Times (1993) Wordpower: Part 1 Literacy, London: The Sunday Times.

The Times of India (2011) Indian women surpass Chinese in financial literacy, 1 March. Available at: http://timesofindia.indiatimes.com/india/Indian-women-surpass-Chinese-in-financial literacy/article show/7602651.cms (accessed 12 December 2012). 


\section{R. M. S. Wilson, A. Abraham and C. L. J. Mason}

Times Higher Education (2007) We must tackle the literacy crisis, THE, 30 March, p. 10.

Turner, J. (2008) Give me credit - I admit I'm financially illiterate, The Times, 20 September, p. 21.

U.S. Financial Literacy and Education Commission (2006) Taking Ownership of the Future: The National Strategy for Financial Literacy. Available at: http://www.mymoney.gov/sites/default/files/downloads/ ownership.pdf (accessed 12 December 2012).

Wagner, E. (2011) Weekly column in The Times (Saturday Review), 13 August, p. 15.

Walters, W. (2012) U.S. students can't compete without math proficiency, Lubbock Avalanche-Journal, 27 February. Available at: http://lubbockonline.com/editorial-columnists/2012-02-27/williams-usstudents-cant-compete-without-math-proficiency\#.UXKcicq6-X8 (accessed 15 April 2013).

Weick, K.E. (1979) The Social Psychology of Organizing, 2nd edn, Reading, MA: Addison-Wesley.

Weick, K.E. (1995) Sense-making in Organizations, Thousand Oaks, CA: Sage.

Weick, K.E., Sutcliffe, K.M., \& Obstfeld, D. (2005) Organizing and the process of sense-making, Organization Science, 16: 409-421.

Whitehead, D.J. \& Halil, T. (1989) The Test of Economic Literacy: Standardization in the U.K., Research Papers in Economics Education, London: Institute of Education, University of London.

Wilde, J. (1991) Visual Literacy: A Conceptual Approach to Graphic Problem-Solving, New York: WatsonGuptill.

Williams-Harold, B. (1999) Saving is fundamental, Black Enterprise, 29, 30.

Willis, L.E. (2009) Evidence and ideology in the assessment of financial literacy, San Diego Law Review, 46, 415. Available at: http://www.papers.ssrn.com/sol3/papers.cfm?abstract_id=1098270 (accessed 12 December 2012).

Wilson, R.M.S. \& Chua, W.F. (1993) Managerial Accounting: Method and Meaning, 2nd edn, London: Chapman \& Hall.

Wilson, R.M.S. \& Gilligan, C.T. (2005) Strategic Marketing Management: Planning, Implementation \& Control, 3rd edn, Oxford: Butterworth-Heinemann.

Wilson. R.M.S. \& Stenson, J.A. (2008) Valuation of information assets on the balance sheet, Business Information Review, 25(3), 167-182.

Wilson, R.M.S. \& Zhang, Q. (1997) Entrapment and escalating commitment in investment decisionmaking: a review, British Accounting Review, 29, 277-305.

Woolcock, N. (2008) Maths may be wrong lesson to learn personal finance, The Times, 25 August, p. 5.

Woolcock, N. (2012) Half of adults have maths skills of a primary pupil, The Times, 2 March, p. 5.

\section{About the authors}

Anne Abraham is Associate Professor in Accounting in the School of Business at the University of Western Sydney, Australia (a.abraham@ues.edu.au). Her major research interests include financial literacy, peer review, scaffolded assessment, and blended learning. Dr Abraham's contributions to accounting education have been recognised by teaching awards, educational consultancies, research grants, and publications.

Carolynne Mason is a Senior Research Associate at Loughborough University, U.K. (c.l.j.mason@lboro.ac.uk) where she completed her PhD on 'Conceptualising Financial Literacy: An Ethnographic Study of School Governors', under Professor Wilson's supervision. Since 2006 she has been an Associate Lecturer with the Open University, U.K., teaching the course 'You and Your Money: Personal Finance in Context'.

Richard M.S. Wilson is Emeritus Professor of Business Administration \& Financial Management at Loughborough University, U.K. (rms.wilson@btinternet.com), founding Editor of Accounting Education: an international journal, a member of the British Accounting \& Finance Association's Hall of Fame, and holds a Lifetime Achievement Award for his contribution to accounting education scholarship and research. 